\title{
Mothers, fathers, or parents: Same-gendered families in South Africa
}

\author{
Carien Lubbe \\ Department of Educational Psychology, Faculty of Education, Groenkloof Campus, All \\ Purpose Building, C114, University of Pretoria, 0001, South Africa \\ carien.lubbe@up.ac.za
}

\begin{abstract}
Advances and changes in globalised culture compel psychologists to take cognisance of the wide variety of ways in which families are formed and in which children grow up. Although members of the gay community have in the past usually been associated with a childless lifestyle, gay people are increasingly opting for motherhood and fatherhood by creating families of their own or by continuing to live with their children from former heterosexual relationships. This article addresses the concept of same-gendered families as an example of the changing face of families, relating it to the hetero-normativity that is embedded in Westernised societies. The dichotomies of sexuality are confronted and used to illuminate the cultural assumptions embedded in the concept 'family' from a postmodern perspective. An overview is given of available research from a South African perspective. Trends evident in local research are related to international perspectives to provide a brief synopsis of available knowledge on same-gendered families. Special attention is given to a postmodern and social constructionist perspective on the concept of family, by examining the gendered and sexualised perceptions that underlie same-gendered families. The interfaces between parenting, gender, sexuality, and reproduction are examined and critically scrutinised. Implications of this for the profession of psychology are briefly discussed. The samegendered couple as a family challenges the normative conceptions of the traditional model of the two-parent (hetero-gender) family because the latter is socially and legally constructed from a biological model of reproduction. The article concludes that structural variables, such as the gender composition of families and the division of parental performances, are less important than process variables such as the quality of relationships and the quality of care given to the children.
\end{abstract}

At the start of the twenty-first century, people are choosing to live their lives and rear their children in associations that only 50 years ago would not have been regarded as families. Societal factors such as working mothers, adoption, divorce, migrant fathers, and HIV/AIDS have all played a part in influencing the ways in which non-traditional family forms have developed. Advances and changes in globalised culture compel people to take cognisance of the wide variety of ways in which families are formed and in which children 
grow up. Such new family arrangements are forcing a redefinition of what is understood, meant, and implied by the concept 'family' (Dunne, 2000; Gottfried \& Gottfried, 1994). One such non-traditional family form that has challenged society's traditional notion of what a family means is the same-gendered family (gay/lesbian family).

Psychologists need to take cognisance of changing family structures in South Africa and elsewhere in the world where people have the liberty to make meaningful changes in their lives. Psychologists should be able to work with people from different backgrounds and perspectives, even when such backgrounds and perspectives are experientially, morally, and spiritually different from their own. In the assessment, therapy, counselling, and consultation of same-gendered families on micro and macro levels, practitioners should be required to attain a certain level of competence. Psychologists need to be sensitive to ways in which people construct their families, and how they might participate and give implicit consent to negative social discourses that are detrimental to the well-being of their clients. This is especially so when seen against the background of the ways in which psychology played a role in the discourse of constructing homosexuality as an illness and how, even today, heterosexuality is still upheld by many psychological approaches as the normal variant of sexuality. This heteronormativity and the resulting implications for samegendered families and the children who are growing up in same-gendered families are addressed in this article.

Little is known about the ways in which same-gendered families operate and function in a predominantly heteronormative society. In addition, limited indigenous research is available, and researchers and practitioners often have to rely on international research. This article therefore highlights the most important research done in South Africa.

This article is based on the assumption that a person with a gay orientation or preference is a healthy, normal individual with essentially the same dreams, passions, hopes, fears, ambitions, aspirations, and the possibility of creating a spiritual richness in being alive as anyone else. However, because of historically negative constructions of homosexual people, living the life of a gay person is not always easy. I assume therefore that every person with a sexual orientation other than heterosexual needs to reconcile his or her sexual orientation somehow with the heteronormativity of society. In the same way that gay people need to do this, so the children of same-gendered parents need to engage in such a process of reconciliation and negotiation.

\section{CHANGING TIMES, STAGNATING CONCEPTS, UNCHALLENGED VIEWPOINTS}

Heteronormativity is evident in most societies. This is also true in South Africa, which is a strongly traditional and family-based society with a culture in which the traditional family is prominent, powerful, visual, and valued (Epstein, O'Flynn, \& Telford, 2002; Hunter \& Mallon, 2000; Johnson, 2004). The traditional nuclear family (which is widely accepted to mean a legally married, two-parent, heterosexual couple) has been the norm 
and benchmark against which all other kinds of couple or family arrangement have been measured and judged. Even when other dominant family structures such as the extended family are included (Ziehl, 2001), heteronormativity remains the norm.

It has to be acknowledged that there have been significant changes in many modern Westernised or semi-Westernised societies. A far greater openness and acceptance is currently evident in popular culture as reflected in mass media. For example, a number of popular television dramas have focused on lesbian or gay characters. There are also indications that some sections of communities have become more accepting of and open to the existence of same-gendered families, and significant legal rulings have been made in favour of same-gender families (De Bruin, 2004; Ellis, 2003; Sullivan, 2003; Truter, 2003; Underhill, 2003). This is a new trend that has emerged only in the past few decades (and more predominantly in the last decade or two). The prevailing discourses of heteronormativity that are becoming increasingly fractured suggest that the extent of the tensions and contradictions that society continues to face is large. Not least of these tensions is the changing structure of what contemporary people regard as the family.

In spite of a greater acceptance of sexual diversity in many quarters, the heterosexual couple remains enshrined as the normative form for adult sexual relationships. As Walters (2000) notes: 'It is hard to believe that the structures of exclusion and discrimination that surround gay life will not in some way impact gay family life' (p. 61). Significant societal biases remain evident in the media, for example in newspaper accounts of legal debates, television debates on moral and religious issues pertaining to the family, the portrayal of families in school textbooks, articles in popular magazines, and legal questions such as the debate that surrounds the sanctioning of marriage between same-gendered couples, and the use of the word 'marriage' to portray such unions (Ellis, 2003; Jackson, 2003; Khan, 2002; Knowler \& Donaldson, 2002; McCafferty, 2001; McGill, 2002; Mphaki, 2003; Powers, 1998; Wallis, 2003). However, descriptions of 'societal attitudes' simply cannot capture the complex and content-specific aspects of everyday thought and practice, the practical reasoning and the gut reactions that inform everyday conduct (Jackson \& Scott, 2004). A study carried out by OUT LGBT Well-being (the Gay, Lesbian, Bisexual, and Transgendered Organisation) in Pretoria, South Africa, revealed, for example, that 37 per cent of a sample of lesbian, gay or bisexual people $(n=487)$ had experienced verbal harassment or abuse because of their sexual orientation while 15 per cent had been asked to leave their faith or religious community because of their sexual orientation (Polders \& Wells, 2004). Because the traditional family structure is widely accepted to mean a family with totally heterosexual parents, most researchers and investigators agree that samegendered families are still stigmatised by society (Barrett, 1997; Coyle \& Kitzinger, 2002; Dunphy, 2000; Kershaw, 2000; Paechter, 2000; Richardson \& Seidman, 2002). To summarise, stigma still attaches to non-heterosexual identities because of heteronormativity, discrimination, and homophobia, and this stigma consequently has an effect on same-gendered families. Because such generally assumed and widely unchallenged belief systems about the ideal family create a dominant narrative of what a 
family is or should be, a perception is created that same-gendered families are different, 'other', and 'alternative'.

Children growing up in same-gendered families are aware of this discrimination and stigmatisation. Jackson and Scott (2004) are of the opinion that the sexual world that children eventually learn about, and come to participate in, continues to be ordered by institutionalised heterosexuality. As children participate in the activities of their schools and churches, and as they watch television or surf the internet, they become aware of - and form their own perceptions of - what a family is or should be. Because of the heteronormativity of Western society, one of the major challenges for every child is the integration of her or his family experience with that of the wider society outside the home. Tasker and Golombok (1997) note that a major challenge for every child and his or her family is the integration of family experience with the expectations and values of the wider society outside their home. Although this is a universal dilemma, integration is more difficult to achieve when a family's divergence from prevailing norms within the wider social group is greater than average.

In order to understand how same-gendered families and the children in same-gendered families have to negotiate their position in the world, psychologists need to understand how life in Western society is dominated by a social discourse of 'straightness'. Therefore I will deconstruct the constructed and hegemonic categories that organise sexuality in a Westerninfluenced society in the following section.

\section{BINARY THINKING IN THE WESTERNISED WORLD: THE HISTORY OF HOMO- AND HETEROSEXUALITY}

Throughout its history, Western thought has been dualistic in its most basic epistemological assumptions. People influenced by these assumptions tend to perceive reality in terms of binaries such as male/female, hetero/homo, black/white, dominant/subordinate, and public/private. These categories for defining particular kinds of relationships and practices are culturally and historically specific and have not operated in all cultures at all times (Richardson \& Seidman, 2002; Sullivan, 2003). Sexual categories reflect deeply held assumptions in Western thought. Whereas other societies such as that of the Ancient Greeks had established categories of active-passive and dominant-subordinate to reflect social relations, Westernised civilisation established naturalised and individualised categories such as man-woman and homosexual-heterosexual (Roseneil, 2002). This does not mean that same-gender relations do not have a long, rich history of existence. However, the rigidly binary terms that are used to frame social and personal understandings of same-gender relations are characteristic of Western thought. As Norton (2002) states: 'The absence of language does not indicate the absence of conceptual thought' (p. 2).

In 1868, Karl M. Kertbeny introduced the term 'homosexuality' into Western-influenced society for the first time, while, in 1880, the word 'heterosexual' was used for the first time in printed form. In terms of these concepts, there are people who can be labelled 
homosexual because of their sexual orientation - and such people exist in a category that is distinct from heterosexual (Richardson \& Seidman, 2002; Sullivan, 2003). When the term 'heterosexuality' was used by medical specialist James Kiernan in 1892, he used it to describe the 'sexual perversion' of individuals who engage in non-procreative sex with the opposite sex for 'pleasure alone' (Dunphy, 2000, p. 6). This specific definition of heterosexuality has also undergone significant changes leading to its current usage indicating healthy sexual development, but that is beyond the scope of this article. Thus, by the end of the twentieth century, people in the West and in Western-influenced societies had become widely accustomed to using only these two categories of sexual labelling to describe the sexual orientation of human beings and manifestations of sexual desire. As Eve Kosofsky Sedgwick says:

What was new from the turn of the century was the world-mapping by which every person, just as he or she was necessarily assignable to a male or female gender, was now considered necessarily assignable as well to a homo- or a hetero-sexuality, a binarised identity full of implications. (1990, p. 3)

The main consequence of the hegemony of this binary model of sexuality is that heterosexuality became privileged (Bernstein \& Reimann, 2001; Dunphy, 2000; Epstein et al., 2002; Esterberg, 2002; Puri, 2002). Since the invention, dissemination, and widespread acceptance of these binary labels, heterosexuality has been considered to be the outcome of a normal and healthy psychosexual development — whereas homosexuality has been considered to be a pathological deviation from that supposed norm (Clunis \& Green, 2000).

Heteronormativity emphasises the correctness of heterosexual dogmas and traditional family forms while at the same time censuring, punishing, 'medicalising', and rendering homosexuality invisible in all of its manifestations. Heteronormativity indicates how heterosexuality dominates in frequently unconscious or inconspicuous ways. Puri (2002) explains that this normativity of heterosexuality - the notion that everyone is unquestioningly assumed to be straight (until proved otherwise) - becomes visible in subtle forms of discrimination, indifference, or unwarranted assumptions. One often encounters such unwarranted assumptions in conversations where references to marriage and relationships are predicated on the universal validity of opposite sex relationships. Thus someone may remark to a woman: 'Are you married?' or 'What does your husband do?'(Puri, 2002, p. 432). Janet Wright (2001) uses the term 'heterosexual supremacy' to describe our largely heterosexual-supremacist societies in which the 'male/female bond is idealised as naturally spiritually, physically, emotionally and intellectually superior' to any other variant form of sexual relationship (p. 278). Heterosexuality is unthinkingly idealised or privileged because it is taken for granted by most people that heterosexuality is 'right, natural and universal' (p. 279). In addition, the laws, institutions, and values of Westerninfluenced societies are predicated on these erroneous assumptions about heterosexuality. Heterosexual supremacy imposes forms of gendered and patriarchal 
society on human beings who do not fit neatly into those categories (Clunis \& Green, 2000; Dunphy, 2000; Epstein et al., 2002). These forms resulted in homosexual people being marginalised and silenced via judicial punishments, imprisonment, and incarceration in private clinics, hospitals, and psychiatric institutions.

From the above discussion it becomes clear that a whole range of ideological assumptions can underlie the perception of even the simplest social interpretations. Many of these assumptions have their roots in the cultural and historical forces that shape and control South African society, and also in conscious attempts by people to interpret and understand the world around them. When working with or encountering same-gendered families, the ideological and cultural context of heteronormativity cannot be ignored.

\section{FOCUSING ON SOUTH AFRICA: BRIEF HISTORY AND CURRENT DISCOURSES}

In South Africa, the discourse on sexuality was also rigidly controlled by the apartheid system. While a blind eye was turned to the history of black male homosexuality in the mine compounds, incidents of white middle-class homosexual encounters were intensely scrutinised by the state (Elder, 1995; Gevisser \& Cameron, 1994).

Duringthe 1970s, the (mostly white) gay subculture ofboth men and women underwent an expansion, mostly because of increased urbanisation, the effects of the women's liberation movement, the human rights movement, and greater post-World War II acceptance of a 'single' lifestyle. Developments in media might also have improved communication and this meant that homosexuals of both genders were able to follow (to some extent) the ideological and political trends of the gay liberation movement in the United States and the United Kingdom. This was limited, however, in that censorship laws during the apartheid years prevented all but the most innocuous texts from entering the country.

Lesbian and gay voices are no longer silent in South Africa, and a relatively new (lesbian and gay) voice that is starting to speak out is that of the same-gendered family. Although they once lived on the margins of society, same-gendered families are also emerging as part of a 'collective' gay community. In South Africa in particular, the terms of the new Constitution give gay people permission to advocate their right to establish life partnerships, become eligible to adopt children, keep custody of their own children in divorce proceedings, and, more recently, to be able to establish co-parenting. In spite of this, real-life attitudes towards gay and lesbian people are slow to change (Cameron-Ellis, 1999; Knoesen, 2004; Singh, 1995). Acceptance and understanding that is characterised neither by silence nor by open judgement and condemnation will naturally grow slowly after decades of bigotry, persecution, and discrimination because these negative attitudes are deeply embedded in the societal matrix. South African society still exhibits signs of a culture of discrimination and judgement. Because of the legacy of South Africa's historically race-determined and neo-colonial system of capitalism in which 'great men' 
dominated history textbooks, the points of view of workers, women, LGBT people, and people from lower socio-economic strata were seldom heard (Bozzoli, 1987, p. xiv).

South Africa has a long history of deliberate disruptions of family life that in the past were sanctioned by law. This has, however, changed over the course of the last decade in particular. Eurocentric and patriarchal definitions of the family are being replaced by more inclusive definitions that take into account (among other factors) the role of culture, gender, history, sexual orientation, autonomy, and religion in determining family relationships (Knoesen, 2003, p. 2).

Scientific literature on same-gendered families and parenting remains limited in South Africa. Until the late 1980s and early 1990s, much of the literature documented the fact that homosexuality was regarded as deviant and criminal behaviour, and same-gendered parents were believed to have a negative and even a corrupting influence on children's development (Botha, 1992; Botha, 2000; Van Niekerk, 1989). A literature search for the key words 'gay/lesbian/homosexual/parent' on relevant databases such as Eric, Psychlnfo, Nexus, ISAP, and SA National Bibliography produced 25 references that have appeared since the year 2000. Five master's degree dissertations have been completed in this field, of which only one focused on parenting (Botha, 2000). The remaining 20 references were to magazine articles in popular magazines, such as Sarie, Huisgenoot, Drum, Femina, and Root Rose. Some articles on donor insemination have been published recently, although also in popular magazines (Fulton, 2004; Underhill, 2003; Von Geusau, 2003). Relevant literature on same-gendered families and parenting indigenous to South Africa remains rare. There is, however, more literature available with regard to different types of sexuality and masculinity, gender, and broader GLBT (gay, lesbian, bisexual, and transgender) issues (Cock, 2003; Kheswa \& Wieringa, 2005; Potgieter, 2004).

From the beginning of the 1990s (and in tandem with the political changes in our country), reviews and commentaries that dealt with custody cases and the right to adoption began to appear in law journals (Bonthuys, 1994; Clark, 1998; De Vos, 1994; Jordaan, 1998; Mosikatsana, 1996; Pantazis, 1996; Singh, 1995; Van der Linde, 1995). This is similar to the international trend where the legal concerns for the welfare of the child with samegendered parents prompted research into same-gendered families. As a result, some legal cases are breaking new ground for same-gendered parents and their children.

In 1993, even before the Equality Clause of the Constitution appeared, a court ruled that a divorced mother could not be denied access to her children because of her lesbian relationship (Isaack, 2003). In April 1998, a lesbian mother won custody of her child after the child had been removed by the Department of Social Services and placed in the care of its grandparents (Powers, 1998). In November 1998, a male gay couple was awarded custody of a child that they had fostered since birth (Oliver, 1998). In September 2002, the Child Care Act and Guardianship Act were formally changed after the groundbreaking case of De Vos and Du Toit, who jointly adopted two children. Another important judgement followed in November 2002 when a lesbian couple were together recognised as their twins' lawful parents (Cole, 2002). This case was also taken to the Constitutional 
Court, which declared the Children's Status Act to be unconstitutional. This act deals with the legitimation of children conceived by artificial insemination. Up to that point, it only made provision for 'a woman' and 'her husband' to be registered as the parents of their children (Ellis, 2003, p. 9). The judge who wrote the judgement for this case noted that changes in the legislation that regulates relationships between gays and lesbians were also necessary. Although gay people could now legally be parents, they still could not be legally married (Mphaki, 2003). In the reactions that followed these cases, the discriminatory attitudes of many religious leaders were strongly apparent (Jackson, 2003; Mphaki, 2003; Whisson, 2003), reinforcing the belief that a normative heterosexist culture still prevails in the minds of many South Africans.

At the end of 2004, an internationally groundbreaking court order ruled that the Constitution should be amended so that it would include marriages between two people of the same gender, although after a mere three weeks the Department of Home Affairs approached the Constitutional Court to appeal against this ruling (De Bruin, 2004; Jackson \& Scott, 2004). The Supreme Court of Appeals declared the common law prohibition of same-gender marriages unconstitutional. However, the Marriage Act of 1961 remained unchanged until January 2006, when another court ruling ordered an amendment to this act as well, changing the 'vows taken by husband and wife' to those of life partners.

The various reactions to the proposed changes to the Marriage Act reflect some of the discourses that inform arguments against same-gender marriages. Four main arguments against same-gender marriages can be identified, which impact directly on the status and recognition of same-gendered families (Knoesen, 2003). First, the discourse of procreation is used to assert that marriage is created for the purpose of procreation. This is no longer relevant because heterosexual people may marry even if one or both partners are unable to procreate. A change in the regulations of the Human Tissue Act recognises the right of a single woman (irrespective of sexual orientation) to receive donor insemination for the purposes of having and raising children. This discourse on procreation is sometimes integrated with religious groups' objections to same-gender relationships and marriage. The second discourse that Knoesen (2003) mentions is the religious and moral one, which is probably the most deeply entrenched discourse that runs through our society, with views both for and against.

The other two discourses refer to the disintegration of the family and the alleged ill effects that same-gender parenting will have on children (Knoesen, 2003). Families throughout history have taken different forms and they continue to develop. However, the quality of relationships in families is more important than the form or structure of the family. With the high divorce rate that prevails in traditional heterosexual marriages, this narrow definition of what a family entails is also under pressure. The argument that samegendered parents will exert an injurious effect on their children was also used against the validity and the legality of inter-racial marriages (in South Africa), and it could also be logically extended to families of low socio-economic status. While it may be true that children from families of low socio-economic status may be materially and even 
emotionally disadvantaged, neither state nor society has the right to remove these children from their parents. These social changes challenge the view that the traditional nuclear family is the only safe and nurturing space in which to have and rear children.

As mentioned before, documentation of same-gendered families in South Africa is limited, and therefore it is worth briefly analysing the vast literature that emanates from the northern hemisphere, especially that of the United States and the United Kingdom.

\section{WHAT CAN BE LEARNT FROM INTERNATIONAL LITERATURE ON SAME-GENDERED FAMILIES?}

When the literature on same-gendered families is critically analysed, one of the first things that can be observed is the theme of development - how research on same-gendered families between the 1980s and today has developed. The earliest research began by comparing gay and non-gay families, and this is still a current theme in some research (Flaks, Ficher, Masterpasqua, \& Joseph, 1995; Green, Mandel, Hotvedt, Gray, \& Smith, 1986; Kirkpatrick, Smith, \& Roy, 1981; Kurdek, 2006).

From the late 1990s and early 2000s onwards, researchers began to argue for a nondefensive approach to the study of all kinds of same-gendered families. Until the late 1990s, most findings suggested that lesbian and gay parents do not produce children who are inferior (or even slightly different) from the children of other parents. Rare, small differences between gay and non-gay parents were reported in such a way that they favoured gay parents because they portrayed them as being somewhat more nurturing and tolerant, and their children in turn as being more tolerant, empathetic and less aggressive (Demo \& Allen, 1996; Laird, 1994; Tasker \& Golombok, 1995).

It seems as though more recent studies are coming to terms with the realities of the postmodern family condition. These studies begin with a pluralist premise concerning the legitimacy and dignity of diverse family structures, and they ask whether or not and how gay and lesbian families differ — rather than deviate — from non-gay families. These studies attend as much to the differences among same-gendered families as to the differences that make them dissimilar to non-gays, and they explore the particular benefits as well as the burdens that such families bestow on their members (Gabb, 2005; SavinWilliams \& Esterberg, 2000). One may therefore conclude that most researchers now engage in the assimilation and transformation debates that centre on the 'sameness' or 'otherness' of same-gendered families. This tension between 'sameness' and 'otherness' has been introduced by studies conducted from a more social constructionist and critical perspective (Anderssen, Amlie, \& Ytteroy, 2002; Baetens \& Brewaeys, 2001; Clarke, 2002; Stacey \& Biblarz, 2001).

Another theme is that a great deal of the literature focuses on problematic issues of sampling, possible biases in selecting a minority group, and issues of representivity and generalisability. Comparative research sometimes fails to distinguish between single 
heterosexual parents and 'single' gay male or lesbians who are engaged in a partnership (Anderssen et al., 2002; Cheng \& Powell, 2005; Fitzgerald, 1999; Parks, 1998).

The earliest research - almost without exception - commented on the incongruence between parenthood and being gay. A great deal of emphasis was placed on the apparent dichotomies (at that time) of 'father', 'mother', 'parent' versus 'gay'. A discourse about 'protecting the child', which stemmed from the political and legal climate of the times in which the research was carried out, became evident (Bozett, 1987; Cramer, 1986; Demo \& Allen, 1996; Hare \& Richards, 1993; Lott-Whitehead \& Tully, 1993; Pennington, 1987).

The discourse of protection occurred alongside a legal discourse that provided the main impetus for research into gay parenthood and same-gendered families. The legal concerns for the welfare of the children centred on the availability of a father figure to act as a role model in the case of lesbian parents, on the possibility - described as a 'mythical belief that gay parents might molest their own or somebody else's children, on an alleged lack of stability in this type of parental relationship, and on the possible impact of a gay parent's sexual orientation on a child (Causey \& Duran-Aydintug, 1997; Lynch \& Murray, 2000; Patterson \& Redding, 1996). This research was specifically directed at establishing what influence, if any, the parent's own sexual orientation might have on the child's own gender identity and sexual orientation, personal development, and social relations. Some of the research explored the awareness of the parents of the heteronormativity of society and their status as a minority group (Benkov, 1994; Fitzgerald, 1999; Green et al., 1986; Krestan, 1987; Laird, 1996; Lott-Whitehead \& Tully, 1993; Lynch \& Murray, 2000; Pennington, 1987; Riggs, 2005; Victor \& Fish, 1995). These themes usually coincided with research on how parents present themselves to their children (Bozett, 1987; Hare, 1994; Levy, 1992; Pies, 1990; Wind, 1999).

Research into gay parenthood investigated the quality of the relationship between the partners (Bos, Van Balen, \& Van den Boom, 2003; Hequembourg \& Farrell, 1999; Laird, 1996; Levy, 1992; Oswald, 2002; Pies, 1990), and between the parents and their children (Golombok et al., 2003; Green et al., 1986; Tasker, 2002; Wind, 1999). Another topic of investigation has been the division of labour/household chores, child-rearing practices, discipline, and parental style (Gordon, 1990; Green et al., 1986; Harris \& Turner, 1985; Kirkpatricketal., 1981; Segal-Sklar, 1995; Tasker, 2002). These studies typically concluded that household roles are not based on stereotyped heterosexual marital roles, but on the time and talents of the parents involved. Same-gendered parents create their own methods or rules that govern how they relate to one another, and how they present themselves to others and to their children (Kirkpatrick et al., 1981; Lynch, 2000; Parks, 1998; Patterson, 1995; Pies, 1990). Some research focused on the co-mother or the social mother, as well as on the motivation for, and the expectations that parents entertain, with regard to pregnancy and parenthood, the decision-making process, and the value of children to gay parents (Bos et al., 2003; Goldberg \& Sayer, 2006; Siegenthaler \& Bigner, 2000).

A new emphasis that has emerged from the late 1990s onwards is a focus on families created by donor insemination. Themes of this research include the role and level of 
involvement of the donor, the impact of father-absent families from infancy on children, and the psychological adjustment and family structure (Bos et al., 2003; Donovan, 2000; Dundas \& Kaufman, 2000; Golombok, Tasker, \& Murray, 1997; Greenfeld, 2005; Tasker, 2002; Vanfraussen, Ponjaert-Kristoffersen, \& Brewaeys, 2002). Baetens and Brewaeys (2001) concluded that the emotional, behavioural, and psychological development of children of same-gendered parents was very similar to that of children raised in heterosexual families.

One may sum up the available research by saying that the studies concluded that samegender relationships are characterised by mutual commitment and emotional and physical intimacies that are in essence similar or analogous to those that heterosexual couples with children experience. These findings might be applicable to South Africa, but in-depth research is needed to verify this generalisation and to apply it to our specific circumstances, given our advanced Constitution amidst a very strong family-based society.

With this as a background, how can psychologists approach changing concepts of the family, specifically when dealing with same-gendered couples and same-gendered families?

\section{NEW CONCEPTIONS OF THE 'FAMILY'}

The family is perhaps the most timeless, central, and enduring of all social institutions. Because of this, the concept family is often taken for granted and not subjected to the critical scrutiny that it requires. It should therefore be helpful to relay some of the views of feminist scholars who argue that the family is an ideologically based concept, experience, and institution. All the practical, material, and ideological premises that are used in defining the concept family depend on the cultural assumptions about families and gendered relations within families themselves (Dalton \& Bielby, 2000; Gabb, 2001).

Same-gendered families present new challenges to the traditional nuclear family as well as to the extended family structure. Same-gendered families raise suspicions and engender scepticism in some quarters because any departure from the traditional family system and structure raises uncomfortable questions as to the exact nature of a parent, a family, a father, and a mother. Same-gendered families challenge dominant notions not only of gender but also of sexuality. The categories 'lesbian mother' and 'gay father' might seem to imply that a parent's sexual orientation is the most important factor in a gay person's parenting skills. King (2004) argues that people assume that to be gay means being sexual. The very concept of lesbian mother or gay father means that any study of same-gendered families cannot be considered apart from sexuality. The same-gendered family is sexualised in the sense that the concept itself implicitly evokes the sexuality of the parents concerned as well as the dichotomy between homosexuality and heterosexuality. As Loutzenheiser and Macintosh (2004) conclude, the queer family is 'hyper-sexualised'.

Bernstein and Reimann (2001) argue that it is in gay parenting that heteronormativity, and 
therefore the opposition of society, is most powerfully experienced. This happens because the modern Western social construction of sexuality masks a very real groundswell of opposition to the homo/hetero dichotomy and the maintenance of strict sexual borders that such a dichotomy requires. Although its opposition to any blurring of sexual boundaries is usually unspoken and ironically silent, heterosexuality remains the ever-present and influential sub-text of modern sexual discourse.

Because most families convey strong heterosexual messages, they provide many opportunities for their children to receive positive reinforcement, approval, and validation for their heterosexual orientation. Most parents encourage the dating of opposite-gendered individuals, marriage, and eventually children - particularly as adolescence and sexual maturity approach (Hunter \& Mallon, 2000). Even the knowledge and values that are socially constructed in educational settings are constructed along heterosexual lines and are bound up with the organisation and regulation of the heterosexual family. According to Epstein et al. (2002), myths of 'happy heterosexuality' abound at every stage of childhood development - from the playhouse of the nursery school to the dating games of senior primary and secondary schools and universities. Children come to understand that hetero/ homosexuality is a natural dichotomy that 'proves' that heterosexuality is a normal and desirable end in itself. Heterosexual behaviour and language are integrated and imposed to such a degree within the school culture that they have come to constitute a norm that reflects what is 'natural' (p. 272).

Experience can be utilised to construct reality, and children growing up with samegendered parents certainly have experiences that shape their reality. Johnson and O'Connor (2001) state that 'parenting is universal ... But the day-to-day experiences that our family encounter can be unique. The homophobia that surrounds us affects our families in subtle and not so subtle ways' (p. 7). The scarcity of positive images and the abundance of negative stereotypes, as well as the invisibility of same-gendered families in the institutions outside the family, all combine to create a sense of difference, uniqueness, and secrecy (Bernstein \& Reimann, 2001; Wright, 2001).

\section{Queer and postmodern redefinitions of the family}

Heterosexuality and its accompanying destiny in straight nuclear families is still assumed to be a desirable norm for 'ordinary' people, although this singular view can no longer be taken for granted in the realm of academic scholarship (Zimmerman, 1992). Scholars of queer theory argue that gay individuals and families are moving beyond the closet and that a postgay era is emerging (Roseneil, 2002). Ellis and Murphy (1994) state that challenges and alternatives to traditional views about appropriate gender roles and relationships are increasing in psychological practice and theory, and that there is a growing accumulation of data that confirms psychological similarities among couples of different types.

Reflexive heterosexual identities are becoming increasingly widespread, and all over the Western world hetero-relations have a significantly less sure hold on the general 
population across the generations. Roseneil (2002) remarks that, at the beginning of the twenty-first century, there are few families that do not include at least some members who diverge from traditional, normative, hetero-relational practice, whether as divorcees, unmarried mothers and fathers, singles, lesbians, gay men, or bisexuals. She argues that an era of queering the family has begun, as the constituted meaning of family faces radical challenges and more and more kinship groups are coming to terms with the diverse sexual practices and living arrangements chosen by their own family members. Lehr (1999) holds a similar view, namely that the married, co-resident heterosexual couple with children no longer occupies the centre in Western societies and cannot be taken for granted as the basic unit in society. Processes of individualisation and the weakening of the bonds of tradition are increasingly releasing individuals from traditional heterosexual scripts and from the patterns of hetero-relationality that accompany them. Postmodern living arrangements are diverse, fluid, and unresolved, they are constantly chosen and re-chosen, and heterorelations are no longer constructed as hegemonic as they once were.

Scholars of queer theory contribute to the richness of understanding different families and the way in which individuals and society function. It is no longer possible to maintain one privileged view in the world of scholarship at least, and researchers, scientists, scholars, and psychologists should give an accurate account of the diversity and plurality that they encounter in ways in which people live their lives. In being confronted with the notion that sexualities are fluid and open, and the possibility of moving beyond the fixed fundamental categories of homo/hetero binaries, each of us is challenged to be selfreflexive and to actively shape and reshape our lives. It remains to be seen whether or not this is practically possible for everyone, but it certainly calls for a more flexible approach to parenting and the view that is taken of families.

The complexity that can be detected in understanding the concept of family is further evidence of postmodernist influences in the world. Absolute meaning has collapsed in many sectors of society because society itself offers more choice, fragmentation, and diversity (Kidd, 1999). Even though societies have always been ambiguous, variable, conflicted, and changing, conservative notions of 'the family', of what it really means to be 'a man', 'a woman', and to know 'the truth' about sexuality, are all ideas that have been seriously challenged in modern times. Whereas once it was possible to speak simply of 'men and women', a postmodernist sensibility would speak of 'masculinities, femininities and genders' (Plummer, 2003, p. 19).

Plummer (2003) argues that most people live simultaneously in traditional, modern, and postmodern worlds. Old stories endure side by side with the new, because for every new story a rival one may be adduced from the past, and stories about new family configurations are countered by tales of family values and the inevitability of heteronormativity. There will always be opposition to whatever is new and non-traditional. There will always be 'someone who is going to say "No" to the queer, "Don't touch me". Don't touch me because you're sick and you'll contaminate me . . , or you'll contaminate Western civilisation' (Dinshaw, 1999, p. 173). Many prefer to cling to what they falsely idealise as a simpler and 
kinder past because they feel anxious and insecure. They try to preserve their distinctive identity as a person or group in contemporary societies that are changing with bewildering rapidity. Such nostalgic and authoritative voices can be heard emanating from religious fundamentalists of every kind, whether they are the fundamentalists of the religious right from the 'Bible Belt' of the United States or religious fundamentalists from elsewhere. In Western countries, people fight what they regard as a threat to the alleged sanctity of the nuclear family by opposing the legalisation of gay marriages (Kirkpatrick, 2004; Lacayo, 2004), and even in South Africa, homosexual identities have been condemned (McGill, 2002; Prins, 2003; Whisson, 2003).

Coontz (1992) argues that people often yearn for an idealised romantic past that never existed in the first place, or for the kind of happy and devoted family that was alleged to have existed in a world now lost. This kind of family is actually a sentimental delusion that forms part of the happily-ever-after mythology that people hark back to in contradiction of the record of what actually happened. Such pious hopes demonstrate how many of our 'memories' of how families were in the past function primarily as mythical stories that are useful for morale building and family cohesiveness and exclusivity. 'Families have always been in flux and often in crisis; they have never lived up to nostalgic notions about "the way things used to be"' (p. 2).

No universally accepted definition of what is meant by 'family' exists. Families are not 'things' that are done to us, they are happenings, practices, and processes — we 'do' the family through acting in life. Families are made or created through choices and actions in life. The postmodern approach to family is characterised by choice, freedom, diversity, ambivalence, and fluidity. Postmodern interpretations of the family argue that it is no longer possible to claim that any one type of family is 'better', more 'natural', or more 'normal' than another. This latter kind of thinking is a residue of modernist and conservative thought in which social actors searched for fixed meanings about life and ready-made truths according to which life could (and should) be lived (Kidd, 1999, p. 13). This kind of thinking negates a core issue, that family revolves around relationships, and relationships cannot be prescribed or structured and cannot be lived within fixed guidelines.

\section{Gender, reproduction, and parenting}

What lesbian families or their male counterparts succeed in achieving is to transfer the traditional focus away from gender in parenting and families. In addition, the development of reproductive technologies over the past few decades has challenged gender divisions by allowing potential parents to enjoy the advantages of reproduction without engaging in any sexual activity at all with a member of the opposite sex. This has given same-gendered couples opportunities to procreate within the bonds of same-gender relationships (Bernstein \& Reimann, 2001; Ltitzen, 1998; Plummer, 2003). Because of this pioneering work, parenting has also been freed from the bonds of gender and sexual activity undertaken for 
purposes of procreation. The same-gendered couple as a family challenges the normative conceptions of the traditional model of the two-parent (hetero-gender) family because it is socially and legally constructed from a biological model of reproduction.

Same-gendered families offer a post-patriarchal vision of what families could be like if people were willing to abandon centuries of conditioning and accept a gender-neutral discourse that is sympathetic to the kind of feminist legal reform that discards the categories of 'mother' and 'father' and collapses them into the more generic concept of 'parent' (Dunne, 2000, p. 12). The cultural change in the direction of a more egalitarian model of parenting is evident in same-gendered families as same-gendered parental couples find solutions to problems such as how to make time for the children as well as time to earn a living. Same-gendered couples have to consciously negotiate agreed definitions of boundaries, meanings, and the attributes of parenthood that they wish to implement in their lives and families. Same-gendered parents and their children transgress the normative status of heterosexuality in relation to reproduction and the organisation of parenting roles. Activities that are traditionally divided between mother and father are redefined or incorporated. These transgressive modalities offer more opportunities for cooperation and creativity, and in doing so they demonstrate the viability of non-heterosexual parenting models. It is indeed the absence of gender differences that permits a reconstruction of the cultural values of family and parenting (Dalton \& Bielby, 2000; Walters, 2000). The probability that lesbians are more likely to share parenting equally and challenge traditional conservative gender arrangements seems to imply that gender is primarily a function of the division of labour (Dalton \& Bielby, 2000; Malone \& Cleary 2002; Patterson, 1995). This is not to deny that some same-gendered parents replicate heterosexual (male/female) role divisions - a practice that Dunne (2000) calls 'theoretical heterosexism' (p. 134). Some same-gendered couples do indeed play out traditional roles of provider and nurturer/caregiver. However, that is a choice that has to be respected.

Parenting can be understood and analysed culturally in terms of gender. The argument of Judith Butler (1990) is that if gender is a.performance and connected within a heterosexual matrix, and if gender performances can be imitated in ways that are not necessarily linked to fixed gendered identities grounded in nature, bodies, or heterosexuality, then parenting can also be defined in terms of a performance. The argument can be made that we 'do' the family through performing various acts in life, just as we 'do' or perform gender. And just as gender is constructed, so also are families constructed. I therefore argue that both parenting and family are constructed and performed. Gender and parenting should be regarded as fluid variables that shift and change to suit different contexts at different times. What are the implications of this for parenting? They offer people who want to be parents the possibility of choosing, forming, and performing their own individual identities as parents in a way that brings their unique abilities, strengths, skills, and talents into play. This challenges society to disregard the stigmas of the past. Is it inherently important if the mother of a family changes a light bulb or services the car? Or if the father cooks, minds the children, and takes care of the garden? Or indeed if all 
these functions are efficiently performed in a same-gendered family in which the children are loved, nurtured, cared for, and protected? What can be learnt from this is that parental roles, duties, and functions can be performed in a wide variety of ways that are not linked to gender stereotypes. It also makes it clear that if people are willing to relinquish their traditional dogmas and stereotypes about gender and sexuality, structural variables, such as the gender composition of families and the division of parental performances, are less important than process variables such as the quality of relationships and the quality of care given to the children (Clarke, 2000; Dunne, 2000; Malone \& Cleary, 2002; Stacey \& Biblarz, 2001).

\section{CONCLUDING REFLECTIONS}

The twenty-first century invites societies, as never before, to consider the great variety of possible ways in which people may live out our lives. Same-gendered families are exemplars of the increasingly rich and diverse forms that modern Western societies are allowing to emerge. Psychologists need to possess an in-depth understanding of the experiences of same-gendered families, and an in-depth knowledge of the heteronormative factors that influence them. Psychology also needs to take cognisance of the fluidity and flexibility created by postmodernism and social constructionist perspectives and how these factors impact on the way the 'family' is constructed.

In this article I have addressed the concept of same-gendered families as an example of the changing face of families, against the backdrop of the heteronormativity of society, which assumes the normative status of heterosexual families in everyday life. An overview of available research from a South African perspective was given, and related to tendencies occurring in international research. A postmodern and social constructionist perspective on the concept of 'family' examined the gendered and sexualised perceptions that underlie same-gendered families, and the interfaces between parenting, gender, sexuality, and reproduction were examined. I argued that both parenting and family are constructed and performed.

Scientific research regarding same-gendered families may help psychologists to arrive at a better understanding of these families and the realisation that differences can be viewed simply as diversity. Despite all the peculiarities that might distinguish one person or family from another, human beings are more often alike than different. This is the value that samegendered families offer in South Africa and throughout the world - the thought that it does not take a mother and father per se, but a.parent to raise a child.

\section{NOTE}

1. 'Same-gendered family' refers to a family constituted by two gay parents of the same gender (two females or two males), who are involved in an intimate and committed relationship. While 'gender' in this sense refers to the biological sex of the parent, I 
acknowledge that 'gender' is socially constructed. It is because of the effect of this construction that I refer to such families as 'same-gendered' families and not 'samegender' families. Such families are also widely referred to as 'lesbian' or 'gay' families or 'same-sex' families.

\section{REFERENCES}

Anderssen, N, Amlie, C, \& Ytteroy, E. A. (2002). Outcomes for children with lesbian and gay parents: A review of studies from 1978 to 2000. Scandinavian Journal of Psychology, 43, 335-351.

Baetens, P., \& Brewaeys, A. (2001). Lesbian couples requesting donor insemination: An update of the knowledge with regard to lesbian mother families. Human Reproduction Update, 7(5), 512-519.

Barett, S. E. (1997). Children of lesbian parents: The what, when and how of talking about donor identity. Women \& Therapy, 20(2), 43-55.

Benkov, L. (1994). Reinventing the family: The emerging story of lesbian and gay parents. New York: Crown.

Bernstein, M., \& Reimann, R. (2001). Introduction. In M. Bernstein \& R. Reimann (Eds.), Queer families, queer politics (pp. 1-17). New York: Columbia University Press.

Bonthuys, E. (1994). Awarding access and custody to homosexual parents of minor children. Stellenbosch Law Review, 5(3), 298-313.

Bos, H. M. W., van Balen, E, \& van den Boom, D. C. (2003). Planned lesbian families: Their desire and motivation to have children. Human reproduction, 18(10), 22162224.

Botha, A. (1992). Die ontwikkeling van homoseksualisme by die vrou. Unpublished D. Phil thesis, University of Pretoria, South Africa.

Botha, K. S. (2000). Die invloed van die ouer se homoseksuele verbintenis op die adolessent: 'n Maatskaplike werkondersoek. Unpublished master's dissertation, University of Pretoria, South Africa.

Bozett, F. W. (1987). Gay and lesbian parents. New York: Praeger. Bozzoli, B. (Ed.). (1987). Class, community and conflict. Johannesburg: Ravan Press. Butler, J. (1990). Gender trouble: Feminism and the subversion of identity. London: Routledge Falmer.

Cameron-Ellis, J. A. (1999). Church and homosexuality: The relationship between individual religious beliefs, attitudes and the quality of contact. Unpublished master's dissertation, University of Pretoria, South Africa.

Causey, K. A., \& Duran-Aydintug, C. (1997). Tendency to stigmatise lesbian mothers in custody cases. In C. A. Everett (Ed.), Child custody, legal decisions and family outcomes (pp. 171-182). New York: Haworth Press.

Cheng, S., \& Powell, B. (2005). Small samples, big challenges: Studying atypical family forms. Journal of Marriage and the Family, 67(4), 926-935. 
Clark, B. (1998). Competing custody rights. Comparative and International Law Journal of Southern Africa, 57(3), 288-306.

Clarke, V. (2000). 'Stereotype, attack and stigmatize those who disagree': Employing scientific rhetoric in debates about lesbian and gay parenting. Feminism \& Psychology, 10(1), 152-159.

Clarke, V. (2002). Sameness and difference in research on lesbian parenting. Journal of Community and Applied Social Psychology, 12, 210-222. Clunis, D. M., \& Green, G. D. (2000). The lesbian parenting book (2nd ed.). New York: Seal Press.

Cock, J. (2003). Engendering gay and lesbian rights: The equality clause in the South African constitution. Woman's Studies International Forum, 26(1), 35-45.

Cole, B. (2002, November 3). Egg-static! Court rules for lesbian parents. Sunday Tribune, p. 1.

Coontz, S. (1992). The way we never were: American families and the nostalgia trip. New York: Basic Books.

Coyle, A., \& Kitzinger, C. (2002). Lesbian \& gay psychology. London: Blackwell.

Cramer, D. (1986). Gay parents and their children: A review of research and practical implications. Journal of Counselling and Development, (54(8), 504-507.

Dalton, S. E., \& Bielby, D. D. (2000). That's our kind of constellation: Lesbian mothers negotiate institutionalised understandings of gender within the family. Gender \& Society, 14(1), 36-61.

De Bruin, P. (2004, December 1). Huwelikshek oop, skerp reaksie op hof se groen lig vir gays wat wil trou. Beeld, p. 1.

Demo, D. H., \& Allen, K. R. (1996). Diversity within lesbian and gay families: Challenges and implications for family theory and research. Journal of Social and Personal Relationships, 13(3), 415-434.

De Vos, P. (1994). The right of a lesbian mother to have access to her children: Some constitutional issues. South African Law Journal, 111(4), 687-694.

Dinshaw, C. (1999). Getting medieval: Sexualities and communities, pre-andpost-modern. Durham, NC: Duke University Press.

Donovan, C. (2000). Who needs a father? Negotiating biological fatherhood in British lesbian families using self-insemination. Sexualities, 3(2), 149-194.

Dundas, S., \& Kaufman, M. (2000). The Toronto lesbian family study. Journal of Homosexuality, 40(2), 65-79.

Dunne, G A. (2000). Opting into motherhood: Lesbians blurring the boundaries and transforming the meaning of parenthood and kinship. Gender \& Society, 14(1), 11-35.

Dunphy, R. (2000). Sexual politics: An introduction. Edinburgh: Edinburgh University Press.

Elder, G. (1995). Of moffies, kaffirs and perverts: Male homosexuality and the discourse of moral order in the apartheid state. In B. David \& V. Gill (Eds.), Sexuality (pp. 5665). London: Routledge Falmer.

Ellis, E. (2003, February 9). Same-sex parents can raise family, says court. Star, p. 3. 
Ellis, P., \& Murphy, B. C. (1994). The impact of misogyny and homophobia on therapy with women. In M. P. Mirkin (Ed.), Women in context: Toward a feminist reconstruction of psycho-therapy (pp. 48-73). New York: Guilford Press.

Epstein, D., O'Flynn, S., \& Telford, D. (2002). Innocence and experience: Paradoxes in sexuality and education. In D. Richardson \& S. Seidman (Eds.), Handbook of lesbian and gay studies (pp. 271-290). London: Sage.

Esterberg, K. G. (2002). The bisexual menace: Or, will the real bisexual please stand up? In D. Richardson \& S. Seidman (Eds.), Handbook of lesbian and gay studies (pp. 215-227). London: Sage.

Fitzgerald, B. (1999). Children of lesbian and gay parents: A review of the literature. Marriage \& Family Review, 29(1), 57-75.

Flaks, D. K., Ficher, I., Masterpasqua, F., \& Joseph, G. (1995). Lesbians choosing motherhood: A comparative study of lesbians and heterosexual parents and their children. Developmental psychology, 31(1), 105-114.

Fulton, C. (2004, February). They said it wouldn't last. Fair Lady, pp. 72-75.

Gabb, J. (2001). Querying the discourses of love. The European Journal of Women's Studies, 8(3), 313-328.

Gabb, J. (2005). Locating lesbian parent families: Everyday negotiations of lesbian motherhood in Britain. Gender Place and Culture, 12(4), 419-432.

Gevisser, M., \& Cameron, E. (Eds.). (1994). Defiant desire. Johannesburg: Ravan Press.

Goldberg, A. E., \& Sayer, A. (2006). Lesbian couples' relationship quality across the transition to parenthood. Journal of Marriage and the Family, 68(1), 87-100.

Golombok, S., Perry, B., Burston, S., Murray, C, Mooney-Somers, J., Stevens, M., et al. (2003). Children with lesbian parents: A community study. Developmental Psychology, 39(1), 20-33.

Golombok, S., Tasker, F., \& Murray, C. (1997). Children raised in fatherless families from infancy: Family relationships and the socio-emotional development of children of lesbian and single heterosexual mothers. Journal of Child Psychology and Psychiatry and Allied Disciplines, 38(1), 783-791.

Gordon, T. (1990). Feminist mothers. London: Macmillan.

Gottfried, A. E., \& Gottfried, A. W. (Eds.). (1994). Redefining families, implications for children's development. New York: Plenum Press.

Green, R., Mandel, J. B., Hotvedt, M. E., Gray, J., \& Smith, L. (1986). Lesbian mothers and their children: A comparison with solo parent heterosexual mothers and their children. Archives of Sexual Behaviour, 15(2), 167-184.

Greenfeld, D. A. (2005). Reproduction in same sex couples: Quality of parenting and child development. Current Opinion in Obstetrics \& Gynaecology, 17(3), 309-312.

Hare, J. (1994). Concerns and issues faced by families headed by a lesbian couple. Families in Society, 75(1), 27-35. 
Hare, J., \& Richards, L. (1993). Children raised by lesbian couples: Does context of birth affect father and partner involvement? Family Relations, 42(3), 249-255.

Harris, M. B., \& Turner, P. H. (1985). Gay and lesbian parents. Journal of Homosexuality, 12(2), 101-113.

Hequembourg, A. L., \& Farrell, M. P. (1999). Lesbian motherhood: Negotiating marginal mainstream identities. Gender \& Society, 75(4), 540-557.

Hunter, J., \& Mallon, G. P. (2000). Lesbian, gay and bisexual development: Dancing with your feet tied together. In B. Greene \& G. L. Croom (Eds.), Education, research and practice in lesbian, gay, bisexual and transgendered psychology (pp. 226-243). Thousand Oaks, CA: Sage.

Isaack, W. (2003). Equal in word of law: The rights of lesbian and gay people in South Africa. Retrieved July 19, 2004, from http://www.equality.org.za/legal/articles/ 2003/ equalworldlaw.php

Jackson, N. (2003, August 27). 50\%+ van sinodegangers meen gays sondig. Beeld, p. 4. Jackson, S., \& Scott, S. (2004). Sexual antinomies in late modernity. Sexualities, 7(2), 233-248.

Johnson, P. (2004). Haunting heterosexuality: The homo/het binary and intimate love. Sexualities, 7(2), 183-2000.

Johnson, S. M., \& O'Connor, E. (2001). For lesbian parents: Your guide to helping your family grow up happy, healthy and proud. New York: Guilford Press.

Jordaan, D. W. (1998). Homoseksuele ouerskap: 'n Grondwetlike analise. De Jure ac Legibus, 31(2), 302-321.

Kershaw, S. (2000). Living in a lesbian household: The effects on children. Child and Family Social Work, 5(4), 365-371.

Khan, F. (2002, September 15). Same-sex adoptions are 'godless'. Sunday Tribune, p. 3.

Kheswa, B., \& Wieringa, S. (2005). My attitude is manly ... a girl needs to walk on the aisle: Butch-femme culture in Johannesburg, South Africa. In Morgan, R. \& Wieringa, S. (Eds.), Tommy boys, lesbian men and ancestral wives: Female same-sex practices in Africa (pp. 199-229). Johannesburg: Jacana Press.

Kidd, W. (1999). Family diversity in an uncertain future. Sociology Review, 9(1), 11-14.

King, J. R. (2004). The (Impossibility of gay teachers for young children. Theory into Practice, 43(2), 22-127.

Kirkpatrick, D. D. (2004, February 28). Gay-marriage fight finds ambivalence from evangelicals. New York Times. Retrieved March 2, 2004, from http://nytimes.com

Kirkpatrick, M., Smith, C, \& Roy, R. (1981). Lesbian mothers and their children: A comparative study. American Journal of Orthopsychiatry, 57(3), 545-551.

Knoesen, E. (2003). Speech to OUTAGM2003. Retrieved July 19, 2004, fromhttp://www. equality.org.za/archive/2-3/outagm.php

Knoesen, E. (2004, March 3). Queering the vote. Mail \& Guardian, p. 15.

Knowler, W., \& Donaldson, H. (2002, September 15). Gay couples celebrate adoption law. Sunday Tribune, p. 3. 
Krestan, J. (1987). Lesbian daughters and lesbian mothers: The crisis of disclosure from a family system perspective. Journal of Psychotherapy \& the Family, 5(4), 113-130.

Kurdek, L. A. (2006). Differences between partners form heterosexual, gay and lesbian cohabiting couples. Journal of Marriage and Family, 68(2), 509-528.

Lacayo, R. (2004). For better or for worse? Time Magazine, 163(10), 18-25. Laird, J. (1994). Lesbian families: A cultural perspective. In M. P. Mirkin (Ed.), Women in context: Toward a feminist reconstruction of psycho-therapy (pp. 118-148).New York: Guilford Press.

Laird, J. (1996). Family-centred practice with lesbian and gay families. Families in Society, 77(9), 559-572.

Lehr, V. (1999). Queer family values. Philadelphia: Temple University Press.

Levy, E. F. (1992). Strengthening the coping resources of lesbian families. Families in Society, 73(1), 23-31.

Lott-Whitehead, L., \& Tully, C. T. (1993). The family lives of lesbian mothers. Smith College Studies in Social Work, 63(3), 265-280.

Loutzenheiser, L. W., \& Macintosh, L. B. (2004). Citizenships, sexualities and education. Theory into Practice, 42(2), 151-158.

Ltitzen, K. (1998). Gay and lesbian politics: Assimilation or subversion: A Danish perspective. In J. Lofstrom (Ed.), Scandinavian homosexualities: Essays on gay and lesbian studies (pp. 233-244). New York: Haworth Press.

Lynch, J. M. (2000). Considerations of family structure and gender composition: The lesbian and gay step family. Journal of Homosexuality, 40(2), 81-95.

Lynch, J. M., \& Murray, K. (2000). For the love of the children: The coming out process for lesbian and gay parents and stepparents. Journal of Homosexuality, 39(1), 1-24.

Malone, K., \& Cleary, R. (2002). (De)Sexing the family. Feminist Theory, 5(3), 271-293.

McCafferty, C. (2001, October 9). Children without fathers more crime-prone. Eastern Province Herald, p. 4.

McGill, J. (2002, September 26). Ruling reflects moral problem. The Herald, p. 7.

Mosikatsana, T. (1996). Comment on the adoption by K and B, re (1995)31 CRR(2d)151. South African Journal on Human Rights, 12(4), 582-586.

Mphaki, A. (2003, April 20). Same-sex couples get equality and disapproval. City Press, p. 21.

Norton, R. (2002). A critique of social constructionism and postmodern queer theory: 'Labelling theory'. Retrieved February 25, 2005, from http://www.inoopt.demon. co.uk/social21.htm

Oliver, L. (1998, December 5). Tears as pair is given custody. Saturday Argus, p. 3.

Oswald, R. F. (2002). Resilience within the family networks of lesbian and gay men: Intentionally and redefinition. Journal of Marriage and the Family, 64(2), 374-383.

Paechter, C. (2000). Growing up with a lesbian mother: A theoretical based analysis of personal experience. Sexualities, 5(4), 395-408. 
Pantazis, A. (1996). The problematic nature of gay identity. South African Journal on Human Rights, 12(2), 291-307.

Parks, C. A (1998). Lesbian parenthood Areview of literature. American Orthopsychiatric Association, 86(3), 376-389.

Patterson, C. J. (1995). Families of the lesbian baby boom: Parents' division of labor and children's adjustment. Developmental Psychology, 31(1), 115-123.

Patterson, C. J., \& Redding, R. E. (1996). Lesbians and gay families with children: Implications of social science research for policy. Journal of Social Issues, 52(3), 2950.

Pennington, S. B. (1987). Children of lesbian mothers. In F.W. Bozett (Ed.), Gay and lesbian parents (pp. 58-74). New York:

Praeger. Pies, C. A. (1990). Lesbians and the choice to parent. Marriage and Family Review, 14(3-4), 137-154.

Plummer, K. (2003). Intimate citizenship: Private decisions and public dialogues. Seattle, WA: University of Washington Press.

Polders, L., \& Wells, H. (2004). Overall research findings on levels of empowerment among LGBT people in Gauteng, South Africa. Pretoria: OUT LGTB Well-being.

Potgieter, C. (2004). Sexualities? Hey, this is what Black, South African lesbians have to say about relationships with men, the family, heterosexual women and culture. In van Zyl, M. \& Steyn, M. (Eds.), Performing queer: Shaping sexualities 1994-2004 (Vol. 1.) (pp. 177-192). Cape Town: Kwela Books.

Powers, C. (1998, April 3). Lesbian mother wins custody of her child. The Star, p. 3.

Prins, J. (2003, November 11). Gays wat nie skrik, sal hel toe gaan, se gospelsanger. Beeld. Retrieved November 1l,2003,from http://152.111.1.251/argief/berigte/beeld/2003/ll/ll/ B3/03/05.html

Puri, J. (2002). Nationalism has a lot to do with it! Unravelling questions of nationalism and transnationalism in lesbian/gay studies. In D. Richardson \& S. Seidman (Eds.), Handbook of lesbian and gay studies (pp. 427-442). London: Sage. Richardson, D., \& Seidman, S. (2002). Introduction. In D. Richardson \& S. Seidman (Eds.), Handbook of lesbian and gay studies (pp. 1-15). London: Sage.

Riggs, D. W. (2005). 'Rather like a conspiracy theory': Refusing heteronormative understandings of lesbian and gay parents. Australian Journal of Psychology, 57, 249249.

Roseneil, S. (2002). The heterosexual/homosexual binary: Past, present and future. In D. Richardson \& S. Seidman (Eds.), Handbook of lesbian and gay studies (pp. 27-44). London: Sage.

Savin-Williams, R. C, \& Esterberg, K. G. (2000). Lesbian, gay and bi-sexual families. In D. H. Demo, K. R. Allen, \& M. A. Fine (Eds.), Handbook of family diversity (pp. 197-215). Oxford: Oxford University Press.

Sedgwick, E. K. (1990). Epistemology of the closet. Berkeley, CA: University of California Press. 
Segal-Sklar, S. (1995). Lesbian parenting: Radical or retrograde? In K. Jay (Ed.), Dyke life: From growing up to growing old, a celebration of lesbian experience (pp. 174191). New York: Basic Books.

Siegenthaler, A. L., \& Bigner, J. J. (2000). The value of children to lesbian and non-lesbian mothers. Journal of homosexuality, 39(2), 73-91.

Singh, D. (1995). Discrimination against lesbians in family law. South African Journal on Human Rights, 77(4), 571-581.

Stacey, J., \& Biblarz, T. J. (2001). (How) does the sexual orientation of parents matter? American Sociological Association, 66(2), 159-183.

Sullivan, N. (2003). A critical introduction to queer theory. Edinburgh: Edinburgh University Press.

Tasker, F. (2002). Lesbian and gay parenting. In A. Coyle \& C. Kitzinger (Eds.), Lesbian and gay psychology: New perspectives (pp. 81-97). London: Blackwell.

Tasker, E, \& Golombok, S. (1995). Adults raised as children in lesbian families. American Journal of Orthopsychiatry, 65(2), 203-215.

Tasker, E, \& Golombok, S. (1997). Growing up in a lesbian family: Effects on child development. New York: Guilford Press.

Truter, R. H. (2003, April 22). Gay-regte nie ligte besluit. Die Burger, p. 10.

Underhill, G. (2003, June). The story of us. Femina, pp. 72-75.

Van der Linde, S. (1995). Egskeidingsgeding: Toesig oor middeljarige kinders. Codicillus, 36(1), 61-62.

Vanfraussen, K., Ponjaert-Kristoffersen, I., \& Brewaeys, A. (2002). What does it mean for youngsters to grow up in a lesbian family created by means of donor insemination? Journal of Reproductive and Infant Psychology, 20(4), 237-252.

Van Niekerk, E. (1989). Seksuele ontsporinge by seuns in die puberteit. Unpublished master's dissertation, University of Pretoria, South Africa.

Victor, S. B., \& Fish, M. C. (1995). Lesbian mother and the children: A review for school psychologists. School Psychology Review, 24(3), 456-479.

Von Geusau, R. (2003, August). How to make a baby. Shape, pp. 68-71.

Wallis, C. (2003, August 18). A house divided. Time Magazine, pp. 44-45.

Walters, S. D. (2000). Wedding bells and baby carriages: Heterosexuals imagine gay families, gay families imagine themselves. In M. Andrews, S. D. Sclater, C. Squire, \& A. Treacher (Eds.), Lines of narrative (pp. 48-63). London: Routledge Falmer.

Whisson, M. (2003, May 5). Morals matter: Same sex marriages. Daily Dispatch, p. 3. Wind, L. H. (1999). Developmental identity crisis in non-traditional families. In N. B. Webb (Ed.), Play therapy with children in crisis (pp. 318-338). New York: Guilford Press.

Wright, J. M. (2001). Aside from one little, tiny detail, we are so incredibly normal: Perspectives of children in lesbian step families. In M. Bernstein \& R. Reimann (Eds.), Queer families, queer politics (pp. 272-290). New York: Columbia University Press. 
Ziehl, S. C. (2001). Documenting changing family patterns in South Africa: Are census data of any value? Africa Sociological Review, 5(2), 36-62. Zimmerman, B. (1992). Lesbians like this and that. In S. Munt (Ed.), New lesbian criticism (pp. 1-15). New York: Columbia University Press. 